\title{
Study of Coffee Plant Propagation (Coffea spp) with Leaf Cut
}

\author{
Budi Setiawan $^{1}$, Ahmad Rafiqi Tantawi ${ }^{1}$, Azhari ${ }^{1}$ \\ ${ }^{1}$ Faculty of Agriculture, University of Medan Area, Indonesia \\ budiumafp@gmail.com
}

\begin{abstract}
Coffee (Coffea spp) is mostly useful as a beverage is not foreign not only for the nation of Indonesia, but also for various nations in the world. One way to increase yields and extend the life of coffee plants is by pruning. From the results of this pruning of course produces quite a lot of leaves are wasted, so it takes science and technology cultivation of coffee plants by utilizing the coffee leaves. In this study will discuss about the Study of Coffee Plant Propagation (Coffea spp) With Leaf Cut. The research was conducted in March - June 2011 in Galang Suka Village, Galang Subdistrict, Deli Serdang Regency. This research was conducted by Randomized Complete Design (RAL) Factorial with two factors. The first factor is a coffee leaf $(D)$ consisting of two levels of treatment. D1 = The base of the leaf without the petiole, D2 = Leaf tip. The second factor is Nutrition $(N)$ which consists of six levels of treatment. $N 0=$ Rotone $-F 200 \mathrm{mg} / \mathrm{l}, \mathrm{N} 3=$ Growtone $200 \mathrm{mg} / \mathrm{l}, \mathrm{N} 4=$ Growtone $300 \mathrm{mg} / \mathrm{l}$, $N 5=$ Dekamon $2 \mathrm{cc} / 10$ liters. From the results of the study it can be concluded that leaf tip (D2) cuttings given Growtone $200 \mathrm{mg} / \mathrm{l}$ (N3D2) survive until the end of the study, as well as leaf tip (D2) cuttings given Dekamon 2cc / 10 l (N5D2) although the numbers are only 1.23 and 1.06 and N3D2 is better than N5D2.
\end{abstract}

Keywords : coffee; coffee leaves; cuttings; nutrition

\section{Introduction}

Coffee (Coffea spp) is mostly useful as a beverage is not foreign not only for the nation of Indonesia, but also for various nations in the world. The good smell, the taste is distinctive, delicious, and the properties that can provide body refreshment stimulation make coffee quite familiar to the tongue and favored by many people. Coffee beans contain caffeine which can stimulate the work of the heart and brain, so some people cannot stand drinking coffee. But lately there have been found ways to process coffee beans that can eliminate the caffeine content without removing the distinctive aroma and delicious taste (Nagiyati S \& Danarti, 1990).

In Indonesia coffee plants were first introduced by the VOC in the period between 1696-1699. Planting of these plants was initially only experimental, but because the results were satisfactory, the VOC spread coffee beans to various regions. Furthermore, the VOC issued a regulation "Culture Stelsel" which essentially forced a portion of the population, especially in Java, to be obliged to grow coffee. In Indonesia coffee cultivation is spread from Java, Lampung, West Sumatra, North Sumatra, South Sumatra, and Sulawesi (Nagiyati S \& Danarti, 1990).

The expansion of coffee plantations is not only limited to Plantation Companies, but it is precisely the People's Plantation that is increasingly widespread. Based on data from plantation statistics, the average production of coffee can reach 4.5-5 quintals of coffee / ha / year for Arabica species and 9-13 quintals of coffee / ha / year for Robusta species. From the results of coffee exports, the state receives substantial foreign exchange, and also has a social function in providing employment opportunities for those who need it (AAK, 1998).

One way to increase production and extend the life of coffee plants is by pruning. Usually pruning is done after the harvest, but there are also pruning that is done in the dry season, by removing old shoots or branches, so that the growth of branches is good and 
strong. From the results of pruning, of course it produces enough leaves that are wasted, so it takes science and technology to cultivate coffee plants by utilizing the coffee leaves. Based on these problems, the author feels the need to conduct research with leaf cuttings, which is one alternative to the multiplication of coffee plants from pruned leaves. To find out the number of coffee leaf cuttings that live by giving growth regulators.

\section{Methodology}

The ingredients used were Ateng coffee leaves, Rootone-F (containing Naphthalenesetamide $0.067 \%$, Methyl-1-Naphthalenesetamide $0.013 \%$, Methyl-1Naphthalene acetate $0.033 \%$, Indol-3-Butirat $0.057 \%$, and $4 \%$ Oysters, in packs $750 \mathrm{gr}$ ), Growtone (containing IBA and NAA in packs of 100 gr) and Dekamon (containing Na 2.4 Dinitrophenol $1.73 \mathrm{gr} / 1$, Na 5 Nitroguaiacol $5.45 \mathrm{gr} / 1$, Na Orto Nitrofenol $6.90 \mathrm{gr} / 1$ and $\mathrm{Na}$ Para Nitrofenol $10.35 \mathrm{gr} / 1$ in a $100 \mathrm{ml}$ package). The tools used are cover houses, scissors, transparent plastic, bamboo, analytical scales, hands sprayers / sprayers, sand, bowls, and containers / places for planting media in the form of plastic baskets.

This research was carried out using Factorial Completely Randomized Design (RAL) method with two factors. The first factor was coffee leaf (D) which consisted of two levels of treatment. D1 = The base of the leaf without the stem D2 = The tip of the leaf. The second factor is Nutrition $(\mathrm{N})$ which consists of six levels of treatment. $\mathrm{N} 0=$ Control (without being given nutrition) N1 = Rotone-F $200 \mathrm{mg} / \mathrm{1}$, N2 = Rotone-F $300 \mathrm{mg} / \mathrm{l}$, N3 = Growtone 200 $\mathrm{mg} / \mathrm{l}, \mathrm{N} 4=$ Growtone 300mg $/ 1$ and N5 = Dekamon $2 \mathrm{cc} / 10$ liter. From the treatment above, there were 12 combinations of treatments with three times, then 36 experimental plots were obtained. Each plot contains 10 leaves.

Data from the research results were analyzed statistically using the linear model as follows:

$\mathrm{Yij}=\mu+\tau \mathrm{i}+€ \mathrm{ij}$ where,

Yij : Data caused by the effect of treatment and jth test

$\mu \quad$ : Average

ti : The true effect of the i-treatment

$€ \mathrm{ij}:$ Error effect from the second treatment and jth test

In the research carried out the parameters observed were changes in coffee leaf cuttings every week for 12 weeks and counted the number of leaf cuttings that lived and died.

The process of taking coffee leaves is done at 9:00 a.m. by taking the leaves that are green and still fresh and not attacked by the disease. Taking leaves from sections 10-13 and 5-10 branches so that their age is relatively uniform and not too old and young. In this study 300 leaves were taken, then placed in Tupperware. The leaves are arranged into three layers and each layer is 100 leaves.

Making skeleton shelter uses bamboo with a height of $70 \mathrm{~cm}$ and a width of $1 \mathrm{~m}$ while the distance between arches is $1.05 \mathrm{~m}$. After everything is installed, then tie the bamboo with a rope to each iron arch so that it forms a lid. The installation of transparent plastic is done after all the leaves have been planted, and the length of the plastic used is $6 \mathrm{~m} \times 2.6 \mathrm{~m}$. Shade making is made with $1.2 \mathrm{~m}$ height on the front pole and $1 \mathrm{~m}$ on the back post. The shade length is $5.2 \mathrm{~m}$ and the width is $2 \mathrm{~m}$ and the shade cover is in the form of coconut leaves. Then the protective fence serves to protect shelter houses from livestock and others. 
Provision of planting media is done by means, sand is sifted and then sterilized by steaming in boiling water for \pm 30 minutes, after which the sand is cooled. Then the cooled sand is weighed $2 \mathrm{~kg}$ and then given a bayfolan solution of $2 \mathrm{ml} / 1$ as much as $1 / 2$ liter then shaken until evenly mixed, then pour on the plastic tray / crate which has been arranged then leveled and give a code of treatment on each experimental plot.

Hormone treatment uses synthetic hormones by weighing Rootone-F by using analytic scales as much as $200 \mathrm{mg}$ and $300 \mathrm{mg}$, then Growtone as much as $200 \mathrm{mg}$ and 300 $\mathrm{mg}$. Rootone-F is dissolved in water as much as $200 \mathrm{mg} / 1$ and $300 \mathrm{mg} / 1$ at each different place. Likewise with Growtone as much as $200 \mathrm{mg} / 1$ and $300 \mathrm{mg} / 1$ water also at each different place. Furthermore Dekamon solution was taken using $2 \mathrm{cc}$ syringes, which were dissolved with 10 liters of water and the three types of hormones were applied according to the treatment.

Hormone application is done by dipping the Cuttings section into $1 / 2 \mathrm{~cm}$ high hormone solution from the base of the cuttings with 2 minutes soaking time. Then cut the aerated cuttings for 1 minute, so that the hormones really absorb. After everything is dry the wind is done planting on the media provided in the basket. Planting Cuttings is done by making a planting hole $1 \mathrm{~cm}$ deep to function so that the time of planting cuttings is not damaged due to friction with the planting medium when planting. Then cuttings are planted with a distance of $2 \mathrm{~cm} \times 5 \mathrm{~cm}$ then spray the planting medium with a little water. Then covered with transparent plastic to keep the moisture.

\section{Result and Discussion}

From the results of statistical data analysis at the age of 3 MST obtained, the treatment of $\mathrm{D}_{2}$ was significantly different from $\mathrm{D}_{1}$ while the treatment of $\mathrm{N}$ and its combination were not significantly different, as were observations at the age of 4 MST (Table $1)$.

Table 1. Mean Difference Test Number of Live Cuttings at Age 3 and 4 MST

\begin{tabular}{|c|c|c|c|c|c|c|}
\hline \multirow{3}{*}{ Treatment } & \multicolumn{3}{|c|}{ Age 3 MST } & \multicolumn{3}{|c|}{ Age 4 MST } \\
\hline & \multirow{2}{*}{ Average } & \multicolumn{2}{|c|}{ Notation } & \multirow{2}{*}{ Average } & \multicolumn{2}{|c|}{ Notation } \\
\hline & & 0,05 & 0,01 & & 0,05 & 0,01 \\
\hline $\mathrm{N}_{0}$ & 0,70 & a & A & 0,71 & a & A \\
\hline $\mathrm{N}_{1}$ & 1,18 & a & A & 1,05 & a & A \\
\hline $\mathrm{N}_{2}$ & 0,94 & $a$ & A & 0,88 & $a$ & A \\
\hline $\mathrm{N}_{3}$ & 1,09 & a & A & 1,03 & $a$ & A \\
\hline $\mathrm{N}_{4}$ & 0,94 & a & A & 0,88 & a & A \\
\hline $\mathrm{N}_{5}$ & 1,36 & a & A & 1,18 & a & A \\
\hline $\mathrm{D}_{1}$ & 0,83 & a & A & 0,82 & a & A \\
\hline $\mathrm{D}_{2}$ & 1,24 & $b$ & A & 1,10 & $b$ & A \\
\hline $\mathrm{N}_{0} \mathrm{D}_{1}$ & 0,71 & a & A & 0,71 & a & A \\
\hline $\mathrm{N}_{0} \mathrm{D}_{2}$ & 0,71 & a & A & 0,71 & a & A \\
\hline $\mathrm{N}_{1} \mathrm{D}_{1}$ & 1,10 & $a$ & A & 1,00 & a & A \\
\hline $\mathrm{N}_{1} \mathrm{D}_{2}$ & 1,26 & a & A & 1,10 & a & A \\
\hline $\mathrm{N}_{2} \mathrm{D}_{1}$ & 0,88 & a & A & 0,88 & a & A \\
\hline $\mathrm{N}_{2} \mathrm{D}_{2}$ & 1,00 & a & A & 0,88 & a & A \\
\hline $\mathrm{N}_{3} \mathrm{D}_{1}$ & 0,71 & a & A & 0,71 & a & A \\
\hline
\end{tabular}




\begin{tabular}{lllllll}
$\mathrm{N}_{3} \mathrm{D}_{2}$ & 1,46 & $\mathrm{a}$ & $\mathrm{A}$ & 1,35 & $\mathrm{a}$ & $\mathrm{A}$ \\
$\mathrm{N}_{4} \mathrm{D}_{1}$ & 0,88 & $\mathrm{a}$ & $\mathrm{A}$ & 0,88 & $\mathrm{a}$ & $\mathrm{A}$ \\
$\mathrm{N}_{4} \mathrm{D}_{2}$ & 1,00 & $\mathrm{a}$ & $\mathrm{A}$ & 0,88 & $\mathrm{a}$ & $\mathrm{A}$ \\
$\mathrm{N}_{5} \mathrm{D}_{1}$ & 0,71 & $\mathrm{a}$ & $\mathrm{A}$ & 0,71 & $\mathrm{a}$ & $\mathrm{A}$ \\
$\mathrm{N}_{5} \mathrm{D}_{2}$ & 2,00 & $\mathrm{a}$ & $\mathrm{A}$ & 1,66 & $\mathrm{a}$ & $\mathrm{A}$ \\
\hline
\end{tabular}

Description: Numbers followed by the same letter (lowercase letters) are not significantly different at the 0,05 level and the numbers followed by the same letters (uppercase letters) are not significantly different at the o,01 level

At the age of 5 MST, treatment N3 was not significantly different from N5 but was significantly different from N0, N1, N2, and N4. The D2 treatment was significantly different from D1, whereas the treatment of the combination N5D2 and N3D2 was not significantly different but the two treatments differed very significantly from the other treatments. The N1D2 treatment was not significantly different from N4D1 but was significantly different from the treatment N0D1, N0D2, N1D1, N2D1, N2D2, N3D1, N4D2 and N5D1. Likewise, observations at the age of 6 MST (Table 2).

Table 2. Average Difference Test of Number of Live Cuttings at Age 5 and 6 MST

\begin{tabular}{|c|c|c|c|c|c|c|}
\hline \multirow{3}{*}{ Treatment } & \multicolumn{3}{|c|}{ Age 5 MST } & \multicolumn{3}{|c|}{ Age $6 \mathrm{MST}$} \\
\hline & \multirow{2}{*}{ Average } & \multicolumn{2}{|c|}{ Notation } & \multirow{2}{*}{ Average } & \multicolumn{2}{|c|}{ Notation } \\
\hline & & 0,05 & 0,01 & & 0,05 & 0,01 \\
\hline $\mathrm{N}_{0}$ & 0,71 & $\mathrm{a}$ & A & 0,71 & $\mathrm{a}$ & A \\
\hline $\mathrm{N}_{1}$ & 0,86 & a & A & 0,85 & a & A \\
\hline $\mathrm{N}_{2}$ & 0,71 & a & A & 0,71 & $\mathrm{a}$ & A \\
\hline $\mathrm{N}_{3}$ & 1,03 & b & A & 1,05 & b & A \\
\hline $\mathrm{N}_{4}$ & 0,80 & a & A & 0,80 & a & A \\
\hline $\mathrm{N}_{5}$ & 1,08 & b & A & 1,03 & b & A \\
\hline $\mathrm{D}_{1}$ & 0,74 & a & A & 0,74 & a & A \\
\hline $\mathrm{D}_{2}$ & 0,99 & b & B & 0,97 & b & B \\
\hline $\mathrm{N}_{0} \mathrm{D}_{1}$ & 0,71 & a & A & 0,71 & a & A \\
\hline $\mathrm{N}_{0} \mathrm{D}_{2}$ & 0,71 & a & A & 0,71 & a & A \\
\hline$N_{1} D_{1}$ & 0,71 & a & A & 0,71 & a & A \\
\hline$N_{1} D_{2}$ & 1,00 & b & A & 0,99 & b & A \\
\hline $\mathrm{N}_{2} \mathrm{D}_{1}$ & 0,71 & a & A & 0,71 & a & A \\
\hline $\mathrm{N}_{2} \mathrm{D}_{2}$ & 0,71 & a & A & 0,71 & a & A \\
\hline $\mathrm{N}_{3} \mathrm{D}_{1}$ & 0,71 & a & A & 0,71 & a & A \\
\hline $\mathrm{N}_{3} \mathrm{D}_{2}$ & 1,35 & c & B & 1,35 & c & B \\
\hline $\mathrm{N}_{4} \mathrm{D}_{1}$ & 0.88 & $a b$ & A & 0,88 & $a b$ & A \\
\hline $\mathrm{N}_{4} \mathrm{D}_{2}$ & 0,71 & $\mathrm{a}$ & A & 0,71 & $\mathrm{a}$ & A \\
\hline $\mathrm{N}_{5} \mathrm{D}_{1}$ & 0,71 & a & A & 0,71 & a & A \\
\hline $\mathrm{N}_{5} \mathrm{D}_{2}$ & 1,44 & c & B & 1,35 & c & B \\
\hline
\end{tabular}

Description: Numbers followed by the same letter (lowercase letters) are not significantly different at the 0,05 level and the numbers followed by the same letters (uppercase letters) are not significantly different at the 0,01 level

The results of data analysis at the age of 7 MST were obtained, N3 was not significantly different from N5, but the two treatments differed significantly from other treatments. The treatments of $\mathrm{N} 1$ and $\mathrm{N} 4$ were not significantly different but the two 
treatments differed significantly with the treatments $\mathrm{N} 0$ and $\mathrm{N} 2, \mathrm{~N} 0$ and $\mathrm{N} 2$ were not significantly different. The D2 treatment differs very significantly from D1. The combination of the two treatments showed that N5D2 and N3D2 were not significantly different but were significantly different from other treatments. In addition to the two treatments, the other combination treatments were not significantly different (Table 3).

At the age of 8 MST treatments N5 and N3 were not significantly different, but differed very significantly from the other treatments, $\mathrm{N} 1$ was significantly different from the treatments N0, N2 and N4, while N0, N2 and N4 were not significantly different. The D2 treatment differs very significantly from D1. The combination of N5D2 is not significantly different from N3D2 but differs very significantly from other combination treatments. The N1D2 treatment differs significantly with other treatments except N5D2 and N3D2. The treatments of N0D1, N0D2, N1D1, N2D1, N2D2, N3D1, N4D1, and N5D1 were not significantly different (Table 3 ).

Table 3. Mean Difference Test of Number of Live Cuttings at Age 7 and 8 MST

\begin{tabular}{|c|c|c|c|c|c|c|}
\hline \multirow{3}{*}{ Treatment } & \multicolumn{3}{|c|}{ Age 7 MST } & \multicolumn{3}{|c|}{ Age 8 MST } \\
\hline & \multirow{2}{*}{ Average } & \multicolumn{2}{|c|}{ Notation } & \multirow{2}{*}{ Average } & \multicolumn{2}{|c|}{ Notation } \\
\hline & & 0,05 & 0,01 & & 0,05 & 0,01 \\
\hline $\mathrm{N}_{0}$ & 0,71 & $a$ & A & 0,71 & $a$ & A \\
\hline $\mathrm{N}_{1}$ & 0,80 & $\mathrm{~b}$ & B & 0,80 & $\mathrm{~b}$ & A \\
\hline $\mathrm{N}_{2}$ & 0,71 & $\mathrm{a}$ & A & 0,71 & a & A \\
\hline $\mathrm{N}_{3}$ & 0,97 & c & $\mathrm{C}$ & 0,97 & c & B \\
\hline $\mathrm{N}_{4}$ & 0,80 & $\mathrm{~b}$ & B & 0,71 & a & A \\
\hline $\mathrm{N}_{5}$ & 0,97 & c & C & 0,97 & $\mathrm{c}$ & B \\
\hline $\mathrm{D}_{1}$ & 0,74 & a & A & 0,71 & a & A \\
\hline $\mathrm{D}_{2}$ & 0,91 & $\mathrm{~b}$ & B & 0,91 & $\mathrm{~b}$ & B \\
\hline $\mathrm{N}_{0} \mathrm{D}_{1}$ & 0,71 & a & A & 0,71 & a & A \\
\hline $\mathrm{N}_{0} \mathrm{D}_{2}$ & 0,71 & a & A & 0,71 & a & A \\
\hline $\mathrm{N}_{1} \mathrm{D}_{1}$ & 0,71 & a & A & 0,71 & a & A \\
\hline $\mathrm{N}_{1} \mathrm{D}_{2}$ & 0,88 & $\mathrm{a}$ & A & 0,88 & $\mathrm{~b}$ & B \\
\hline $\mathrm{N}_{2} \mathrm{D}_{1}$ & 0,71 & a & A & 0,71 & a & A \\
\hline $\mathrm{N}_{2} \mathrm{D}_{2}$ & 0,71 & a & A & 0,71 & a & A \\
\hline $\mathrm{N}_{3} \mathrm{D}_{1}$ & 0,71 & a & A & 0,71 & a & A \\
\hline $\mathrm{N}_{3} \mathrm{D}_{2}$ & 1,23 & $\mathrm{~b}$ & B & 1,23 & c & $\mathrm{C}$ \\
\hline $\mathrm{N}_{4} \mathrm{D}_{1}$ & 0,88 & a & A & 0,71 & a & A \\
\hline $\mathrm{N}_{4} \mathrm{D}_{2}$ & 0,71 & a & A & 0,71 & a & A \\
\hline $\mathrm{N}_{5} \mathrm{D}_{1}$ & 0,71 & a & A & 0,71 & a & A \\
\hline $\mathrm{N}_{5} \mathrm{D}_{2}$ & 1,23 & $\mathrm{~b}$ & B & 1,23 & $\mathrm{c}$ & $\mathrm{C}$ \\
\hline
\end{tabular}

Description: Numbers followed by the same letter (lowercase letters) are not significantly different at the 0,05 level and the numbers followed by the same letters (uppercase letters) are not significantly different at the 0,01 level 
Table 4. Mean Difference Test of Number of Live Cuttings at Age 9 and 10 MST

\begin{tabular}{|c|c|c|c|c|c|c|}
\hline \multirow{3}{*}{ Treatment } & \multicolumn{3}{|l|}{ Age 9 MST } & \multicolumn{3}{|c|}{ Age10 MST } \\
\hline & \multirow{2}{*}{ Average } & \multicolumn{2}{|c|}{ Notation } & \multirow{2}{*}{ Average } & \multicolumn{2}{|c|}{ Notation } \\
\hline & & 0,05 & 0,01 & & 0,05 & 0,01 \\
\hline $\mathrm{N}_{0}$ & 0,71 & $a$ & A & 0,71 & $a$ & $\mathrm{~A}$ \\
\hline $\mathrm{N}_{1}$ & 0,71 & a & A & 0,71 & a & A \\
\hline $\mathrm{N}_{2}$ & 0,71 & $a$ & A & 0,71 & a & A \\
\hline $\mathrm{N}_{3}$ & 0,97 & $\mathrm{~b}$ & B & 0,97 & $\mathrm{~b}$ & B \\
\hline $\mathrm{N}_{4}$ & 0,71 & a & A & 0,71 & a & A \\
\hline $\mathrm{N}_{5}$ & 0,97 & $\mathrm{~b}$ & B & 0,97 & $\mathrm{~b}$ & B \\
\hline $\mathrm{D}_{1}$ & 0,71 & a & A & 0,71 & a & A \\
\hline $\mathrm{D}_{2}$ & 0,88 & $\mathrm{~b}$ & B & 0,88 & $\mathrm{~b}$ & B \\
\hline $\mathrm{N}_{0} \mathrm{D}_{1}$ & 0,71 & a & $\mathrm{A}$ & 0,71 & a & A \\
\hline $\mathrm{N}_{0} \mathrm{D} 2$ & 0,71 & a & A & 0,71 & a & A \\
\hline $\mathrm{N}_{1} \mathrm{D}_{1}$ & 0,71 & a & A & 0,71 & $a$ & A \\
\hline $\mathrm{N}_{1} \mathrm{D}_{2}$ & 0,71 & $a$ & A & 0,71 & a & A \\
\hline $\mathrm{N}_{2} \mathrm{D}_{1}$ & 0,71 & a & A & 0,71 & a & A \\
\hline $\mathrm{N}_{2} \mathrm{D}_{2}$ & 0,71 & a & $\mathrm{A}$ & 0,71 & a & A \\
\hline $\mathrm{N}_{3} \mathrm{D}_{1}$ & 0,71 & a & A & 0,71 & a & A \\
\hline $\mathrm{N}_{3} \mathrm{D}_{2}$ & 1,23 & $\mathrm{~b}$ & B & 1,23 & $\mathrm{~b}$ & B \\
\hline $\mathrm{N}_{4} \mathrm{D}_{1}$ & 0,71 & a & A & 0,71 & a & A \\
\hline $\mathrm{N}_{4} \mathrm{D}_{2}$ & 0,71 & $a$ & A & 0,71 & $a$ & A \\
\hline $\mathrm{N}_{5} \mathrm{D}_{1}$ & 0,71 & $a$ & A & 0,71 & a & A \\
\hline $\mathrm{N}_{5} \mathrm{D}_{2}$ & 1,23 & $\mathrm{~b}$ & B & 1,23 & $\mathrm{~b}$ & B \\
\hline
\end{tabular}

Description: Numbers followed by the same letter (lowercase letters) are not significantly different at the 0,05 level and the numbers followed by the same letters (uppercase letters) are not significantly different at the 0,01 level

At the age of 9 MST the results of data analysis showed that N5 and N3 were not significantly different but were very significantly different from other treatments, while treatments N0, N1, N2 and N4 were not significantly different, whereas D2 was very significantly different from D1. This also occurs in the observation of age 10 MST. The combination treatment at age 9 and 10 MST showed that N5D2 was not significantly different from N3D2, but the two treatments differed very significantly from other combination treatments. The other combination treatments are not significantly different, respectively.

Table 5. Average Difference Test Number of Live Cuttings at Age 11 and 12 MST

\begin{tabular}{|c|c|c|c|c|c|c|}
\hline \multirow{3}{*}{ Treatment } & \multicolumn{3}{|c|}{ Age $11 \mathrm{MST}$} & \multicolumn{3}{|c|}{ Age 12 MST } \\
\hline & \multirow{2}{*}{ Average } & \multicolumn{2}{|c|}{ Notation } & \multirow{2}{*}{ Average } & \multicolumn{2}{|c|}{ Notation } \\
\hline & & 0,05 & 0,01 & & 0,05 & 0,01 \\
\hline $\mathrm{N}_{0}$ & 0,71 & $\mathrm{a}$ & A & 0,71 & $\mathrm{a}$ & A \\
\hline $\mathrm{N}_{1}$ & 0,71 & $\mathrm{a}$ & A & 0,71 & a & A \\
\hline $\mathrm{N}_{2}$ & 0,71 & a & A & 0,71 & a & A \\
\hline $\mathrm{N}_{3}$ & 0,97 & c & B & 0,97 & c & B \\
\hline $\mathrm{N}_{4}$ & 0,71 & a & A & 0,71 & a & A \\
\hline $\mathrm{N}_{5}$ & 0,88 & $\mathrm{~b}$ & B & 0,88 & b & B \\
\hline $\mathrm{D}_{1}$ & 0,71 & a & A & 0,71 & a & A \\
\hline $\mathrm{D}_{2}$ & 0,85 & $\mathrm{~b}$ & B & 0,85 & $\mathrm{~b}$ & B \\
\hline
\end{tabular}




\begin{tabular}{|c|c|c|c|c|c|c|}
\hline $\mathrm{N}_{0} \mathrm{D}_{1}$ & 0,71 & a & A & 0,71 & $a$ & A \\
\hline $\mathrm{N}_{0} \mathrm{D} 2$ & 0,71 & a & A & 0,71 & a & A \\
\hline $\mathrm{N}_{1} \mathrm{D}_{1}$ & 0,71 & $\mathrm{a}$ & A & 0,71 & a & A \\
\hline $\mathrm{N}_{1} \mathrm{D}_{2}$ & 0,71 & a & A & 0,71 & a & A \\
\hline $\mathrm{N}_{2} \mathrm{D}_{1}$ & 0,71 & a & A & 0,71 & a & A \\
\hline $\mathrm{N}_{2} \mathrm{D}_{2}$ & 0,71 & a & A & 0,71 & $\mathrm{a}$ & A \\
\hline $\mathrm{N}_{3} \mathrm{D}_{1}$ & 0,71 & a & A & 0,71 & $\mathrm{a}$ & A \\
\hline $\mathrm{N}_{3} \mathrm{D}_{2}$ & 1,23 & c & C & 1,23 & c & C \\
\hline $\mathrm{N}_{4} \mathrm{D}_{1}$ & 0,71 & a & A & 0,71 & a & A \\
\hline $\mathrm{N}_{4} \mathrm{D}_{2}$ & 0,71 & a & A & 0,71 & a & A \\
\hline $\mathrm{N}_{5} \mathrm{D}_{1}$ & 0,71 & a & A & 0,71 & $\mathrm{a}$ & A \\
\hline $\mathrm{N}_{5} \mathrm{D}_{2}$ & 1,06 & b & B & 1,06 & $\mathrm{~b}$ & B \\
\hline
\end{tabular}

Description: Numbers followed by the same letter (lowercase letters) are not significantly different at the 0,05 level and the numbers followed by the same letters (uppercase letters) are not significantly different at the 0,01 level

At the age of 11 and 12 the results of the data analysis showed that N3 was significantly different from $\mathrm{N} 5$ and the two treatments differed significantly from other treatments. The treatments of N0, N1, N2 and N4 are not significantly different. In D2 treatment the difference is very real with D1. The combination of treatments showed that the N3D2 results differed significantly from N5D2 and the two treatments differed significantly from the other treatments, and in addition to these two treatments the other treatments were not significantly different (Table 5). From the observations on the period every week until the age of 12 MST, many coffee leaf cuttings are dead and at the end of the observation the surviving coffee leaf cuttings are in the N3D2 and N5D2 treatments. The results of data analysis showed that the N3D2 treatment and N5D2 treatment were the best compared to other treatments.

From the observations on the period every week until the age of 12 MST, many coffee leaf cuttings are dead and at the end of the observation the surviving coffee leaf cuttings are in the N3D2 and N5D2 treatments. The results of data analysis showed that the N3D2 treatment and N5D2 treatment were the best compared to other treatments.

From the observations on the period every week until the age of 12 MST, many coffee leaf cuttings are dead and at the end of the observation the surviving coffee leaf cuttings are in the N3D2 and N5D2 treatments. The results of data analysis showed that the N3D2 treatment and N5D2 treatment were the best compared to other treatments.

A decrease in the number of leaf cuttings that live may be caused by taking leaves as cuttings that are not old enough so that the water content in the leaves is low as well as the carbohydrate content is low and this does not support the growth of cuttings. This is consistent with what was stated by Harjadi, S. (1995) that the success of leaf cuttings must consider the condition of leaves that have high water content, are of sufficient age, high carbohydrate content and are green in color.

Then another possibility is caused by the maintenance of leaf cuttings on uncontrolled hoods for environmental factors for growth of cuttings, including humidity, temperature, rooting media, nutrients on rooting and light media because these factors are limiting factors. This is in accordance with Gardner's (1991) statement that nutrient requirements on root cuttings media with high $\mathrm{C} / \mathrm{N}$ ratio and Hartman (1983) that the success of leaf cuttings is strongly influenced by rooting media as supporting cuttings during root formation, giving moisture to cuttings, facilitate aeration and drainage, as well as for physiological processes 
carried out cuttings, then the temperature inside the hood is very influential on the growth of cuttings, the temperature for rooting cuttings ranges from $21^{\circ} \mathrm{C}$ to $27^{\circ} \mathrm{C}$ in the morning and afternoon and $15^{\circ} \mathrm{C}$ at night days, too high temperatures can encourage the development of shoots beyond the development of roots and increase the rate of transpiration. With conditions like this, the administration of growth regulators on leaf cuttings does not support leaf cuttings because the cells in leaf cuttings are not able to differentiate and due to the weak support of environmental factors in the hood, the leaf cuttings die. In the D2 treatment there were leaf cuttings which survived until the end of the observation at the age of $12 \mathrm{MST}$. The number of leaf cuttings that survived was 1.23 in the N3D2 treatment, while N5D2 was 1.06 and the results of the N3D2 data analysis differed significantly with N5D2 which meant that N3D2 was better.

This is thought to be the choice of leaves as material for cuttings to be quite old and able to adapt to environmental factors in Sugkup. By giving growth regulators at levels N3 and N5 the condition of leaf cuttings can survive until the end of observation because leaf cuttings have enough ingredients to carry out metabolism such as carbohydrates and enzymes for the process of anabolism and catabolism and cell organelles still perform their functions but growth regulators

\section{Conclusion}

From the results of the study it can be concluded that leaf tip cuttings (D2) given Growtone $200 \mathrm{mg} / 1$ (N3D2) can survive until the end of the study, as well as leaf tip cuttings (D2) given Dekamon 2cc / 101 (N5D2) although the number is only 1.23 and 1.06 and N3D2 is better than N5D2.

\section{References}

AAK.1998. Budidaya Tanaman Kopi. Kanisius. Yogyakarta.

Gardner, Peace, Mitchell, 1991. Fisiologi Tanaman Budidaya. Universitas Indonesia. Jakarta. Hardjadi S, 1995. Pengantar Agronomi. Gramedia. Jakarta.

Hartman and Kester, 1983. Plant Propagation Principle and Practise. Prentice Hall Internasional Inc. Engelwoods Clifs. New Jersy. 253-341.

Nagiyati S \& Danarti.1990. Kopi Budidaya dan Penaganan Lepas Panen. Penebar Swadaya. Jakarta. 